\title{
PELUANG MASYARAKAT PESISIR DI KAMPUNG NELAYAN DALAM UPAYA MENINGKATKAN KEMANDIRIAN EKONOMI MELALUI PENDEKATAN POLITIK LINGKUNGAN
}

\author{
Husnul Isa Harahap \\ Program Studi Ilmu Politik, Universitas Sumatera Utara, Medan \\ husnul.harahap@usu.ac.id
}

\begin{abstract}
ABSTRAK
Abstrak: Masyarakat yang tinggal di kampung nelayan adalah masyarakat yang memiliki masalah yang kompleks. Salah satunya adalah dalam hal masalah kemandirian ekonomi. Studi ini mendeskripsikan masalah tersebut dengan pendekatan politik lingkungan. Studi ini juga mendeskripsikan tentang peluang masyarakat di kampung nelayan dalam upaya meningkatkan kemandirian ekonomi melalui pendekatan politik lingkungan. Temuan studi ini adalah terdapat empat peluang yang dapat dimanfaatkan masyarakat di kampung nelayan dalam upaya meningkatkan kemandirian ekonomi. Peluang pertama adalah menjalankan usaha tambahan dengan melakukan wirausaha ramah lingkungan. Peluang kedua adalah memaksimalkan produksi dengan sistem pertanian terpadu. Peluang ketiga, menggagas dan mewujudkan kampung ekowisata. Peluang keempat, membangun unit usaha bersama seperti koperasi berbasis lingkungan. Studi ini dilakukan dengan menggunakan pendekatan kualitatif. Data dan informasi yang ada diperoleh melalui proses wawancara, dan diskusi pendek, serta melalui penelusuran literatur melalui dokumen elektronik dan dokumen cetak.
\end{abstract}

Kata Kunci: pendekatan politik lingkungan, kemandirian ekonomi, wirausaha ramah lingkungan, ekowisata.

Abstract: People living in nelayan villages (kampung nelayan) have complex problems. One of them is economic autonomy. This study describes the problem with a political ecology approach. This study also describes the opportunities of people in nelayan villages in an effort to increase economic autonomy through a political ecology approach. The findings of this study are that there are four opportunities that can be utilized by communities in nelayan villages in an effort to increase economic autonomy. The first opportunity is to run an additional business by doing eco-friendly entrepreneurship. The second opportunity is to maximize production with integrated farming systems. The third opportunity is to initiate and create an ecotourism village. The fourth opportunity is to build a joint business unit such as an environment-based cooperative. This study was conducted using a qualitative approach. Data and information are obtained by interviews and biref discussions, as well as electronic document literature and printed documents.

Keywords: political ecology approach, economic autonomy, eco-friendly entrepreneurship, ecotourism.

\section{A. LATAR BELAKANG}

Istilah pesisir merupakan istilah yang identik dengan wilayah laut. Menurut Dewi Fatmasari masyarakat pesisir adalah bertempat tinggal di 
wilayah pesisir atau pinggir laut. Masyarakat ini, hidup dan beraktifitas dengan memanfaatkan sumber daya yang ada di wilayah pesisir tersebut (Fatmasari, 2014). Masyarakat pesisir sering juga dianggap berada pada lapisan sosial paling miskin. Terutama jika dibandingkan dengan kelompok masyarakat lain. Misalnya jika dibandingkan dengan masyarakat yang hidup pada sektor pertanian (Fatmasari, 2014).

Masyarakat pesisir di kampung nelayan memiliki masalah yang dapat diidentifikasi. Pertama, sarana dan modal usaha. Masalah ini ini sangat dirasakan masyarakat pesisir di kampung nelayan. Masyarakat pesisir di kampung nelayan masih menggunakan bahan dan alat yang sederhana. Tidak ada pemutakhiran secara Ilmu Pengetahuan dalam proses pengelolaan budidaya ikan/kepiting. Pada umumnya masyarakat ini bahkan tidak pernah mendapatkan pelatihan dan penyuluhan dalam kegiatan usaha budidaya yang dilakukan mereka.

Dalam hal modal, secara umum masyarakat pesisir di kampung nelayan sering meminjam modal dari para tengkulak. Biasanya, hal ini terpaksa dilakukan untuk mendapatkan uang guna keberlangsungan usaha dan juga untuk memenuhi kebutuhan kehidupan.

Kedua, faktor cuaca. Faktor cuaca sangat berpengaruh dalam budidaya. Misalnya budidaya kepiting di kampung nelayan. Cuaca yang kurang baik dapat menyebabkan masyarakat pesisir di kampung nelayan gagal produksi. Keadaan cuaca yang tidak baik juga berpengaruh terhadap kualitas kepiting yang dihasilkan. Misalnya, ketika air naik, menyebabkan kepiting dapat keluar dari kolam mereka. Pada banyak kasus keadaan ini telah menyebabkan berkurangnya jumlah hasil panen.

Ketiga, proses budidaya. Proses budidaya yang dilakukan dengan alat dan pengetahuan seadanya mempengaruhi kualitas dan kuantitas produk kepiting bakau dan produk yang dihasilkan. Keempat, distribusi dan pemasaran. Masyarakat pesisir di kampung nelayan tidak jarang menjual hasil kepiting mereka kepada tengkulak. Hal ini juga yang menjadi faktor mengapa secara umum masyarakat pesisir berpenghasilan rendah.

Kelima, manajemen dan sumber daya manusia. Masyarakat pesisir di kampung nelayan memiliki kendala pengetahun dalam memperluas atau membesarkan usahanya. Terutama dalam hal inovasi. Kendala pengetahuan lain misalnya seperti manajemen keuangan, strategi penjualan yang baik. Termasuk dalam hal kewirausahaan.

Salah satu dampak dari masalah-masalah yang dihadapi oleh masyarakat nelayan tersebut adalah kurangnya kemandirian masyarakat nelayan. Terutama dalam konteks kemandirian ekonomi. Apakah ada peluang bagi masyarakat nelayan untuk meningkatkan kemandiriannya? Studi ini mendeskripsikan peluang-peluang yang dapat dimanfaatkan masyarakat kampung nelayan dalam meningkatkan kemandirian melalui pendekatan politik lingkungan. 


\section{B. METODE PELAKSANAAN}

Pendekatan yang digunakan dalam studi ini adalah pendekatan politik lingkungan. Pendekatan ini dalam Bahasa Inggris sering disebut dengan istilah political ecology. Menurut Anna Zimmer sebagai sebuah pendekatan, politik lingkungan dikembangkan oleh Piers Blaikie tahun 1985 and Blaikie dan Brookfield tahun 1987 (Zimmer, 2010).

Metode studi ini adalah menggunakan metode kualitatif. Data dan informasi yang ada diperoleh melalui proses wawancara dan diskusi pendek, serta melalui penelusuran informasi melalui dokumen elektronik dan dokumen cetak.

\section{HASIL DAN PEMBAHASAN}

Permasalahan yang dihadapi oleh masyarakat nelayan adalah masalah yang pada umumnya terjadi pada masyarakat lain. Oleh sebab itu upaya penyelesaian masalah pada konteks masyarakat tertentu dapat diterapkan pada masyarakat nelayan. Prinsipnya adalah bagaimana agar masyarakat nelayan dapat meningkat kemandiriannya.

Masyarakat nelayan memiliki peluang dalam meningkatkan kemandirian melalui pendekatan politik lingkungan. Studi ini mendeskripsikan empat buah peluang utama berbasis pendekatan politik lingkungan yang dapat dimanfaatkan masyarakat nelayan. Namun, pendekatan ini membutuhkan dukungan kebijakan politik dari pemerintah terutama pemerintah daerah. Kebijakan pemerintah akan efektif jika pemerintah memiliki informasi yang akurat tentang daerah yang akan dibangun. Menurut Syahruddin, Aplikasi Sistem Informasi Wilayah termasuk Desa, dapat digunakan untuk pendataan potensi wilayah tersebut (Syaharuddin, 2017).

Peluang pertama, menjalankan usaha tambahan dengan melakukan wirausaha ramah lingkungan. Misalnya saja melakukan wirausaha jamur tiram. Menurut Rosmayati, (Rosmayati, 2018) usaha jamur tiram usaha yang ramah lingkungan. Bahkan limbah usaha ini (limbah baglog jamur dan pertanian), dapat digunakan untuk menyuburkan tanaman. Limbah ini dapat diolah menjadi kompos. Pengolahan limbah ini dapat dilakukan dengan menggunakan mesin, yaitu mesin pencacah kompos. Menurut Rosmayati, kompos tersebut dapat dimanfaatkan sebagai media tanam sayuran organik. Sistem budidaya yang digunakan adalah vertikultur.

Jamur tiram berpotensi untuk mengatasi masalah ekonomi karena tiga hal. Pertama, karena masa simpan. Kedua, karena kandungan gizinya. Ketiga, karena nilai ekonomisnya. Menurut Rosmayati (Rosmayati, 2018), nilai ekonomisnya dapat ditingkatkan. Jadi, usaha ini dapat menjadi peluang meningkatkan kemandirian masyarakat secara ekonomi melalui pelatihan wirausaha termasuk pemasaran. 
Usaha jamur tiram hanya merupakan salah satu contoh. peluang lain dalam berwirausaha ada banyak. Seperti misalnya membuat kerajinan tangan dari bahan yang sudah tidak terpakai. Bahan yang tidak terpakai tersebut dapat dimanfaatkan untuk membuat kerajinan mainan, kerajinan tangan berupa cenderamata, hiasan, serta kerajinan tangan lain.

Hasil pengabdian masyarakat yang dilakukan oleh Haifaturrahmah (dkk.) (Haifaturrahmah, 2017) memberikan gambaran bahwa kegiatan wirausaha dapat bernuansa ramah lingkungan. Menurut Haifaturrahmah, media tanam ramah lingkungan dapat memanfaatkan botol plastik bekas. Selain itu, kegiatan wirausaha yang menggunakan bahan botol plastik bekas, tidak memerlukan modal yang besar.

Peluang kedua, memaksimalkan produksi dengan sistem pertanian terpadu. Sistem pertanian terpadu memungkinkan masyarakat desa nelayan memanfaatkan lahan secara maksimal dengan memanfaatkan potensi yang tersedia. Sebagai contoh, lahan yang tersedia walau sedikit dapat ditanam pohon cabai. Pupuknya berasal dari kotoran ternak yang ada. Contoh lain diatas kolam dapat ditanam kangkung.

Peluang ketiga, menggagas dan mewujudkan kampung ekowisata. Kampung Ekowisata adalah adalah kampung yang memiliki prinsip ekowisata. Menurut buku Pengantar Ekowisata yang ditulis Eko Sugiarto, ada tujuh prinsip ekowisata. Pertama, mengurangi dampak negative pencemaran lingkungan. Kedua, membangun kesadaran lingkungan. Ketiga, menawarkan pengalaman positif. Keempat, memberikan kontribuasi pada pemeliharaan lingkungan. Kelima, memberikan keuntungan bagi masyarakat lokal. Keenam, ekowisata dapat meningkatkan kepekaan sosial dan kepakaan lingkungan. Ketujuh, ekowisata dapat berkontribusi pada upaya menghormati hak asasi manusia dan juga perjanjian kerja (Sugiarto, 2018).

Menurut Muhammad Basyuni, pada kasus di Desa Lubuk Kertang, Kecamatan Brandan Barat, Kabupaten Langkat Provinsi Sumatera Utara, terdapat tiga strategi tentang pengembangan ekowisata. Strategi pertama adalah dengan meningkatkan pengelolaan ekosistem hutan mangrove. Strategi kedua memperkuat daya daya dukung wilayah Kampung. Strategi yang ketiga menggunakan media internet atau media sosial sebagai alat promosi ekowisata (Basyuni, 2016).

Peluang keempat, membangun unit usaha bersama seperti koperasi berbasis lingkungan. Saat ini sudah banyak contoh pemanfaatan koperasi untuk menjaga lingkungan. Contoh sederhana adalah pengelolaan sampah. Ada dua sudut pandang yang menjadi isu terkemuka pada program ini. Sudut pandang pertama adalah kesejahteraan. Sudut pandang kedua adalah kelestarian lingkungan. Dua sudut pandang ini saling mendukung satu sama lain. 


\section{SIMPULAN DAN SARAN}

Masyarakat pesisir, khususnya yang tinggal di Kampung Nelayan memiliki masalah yang sangat kompleks. Terutama masalah kemandirian ekonomi. Masyarakat ini memiliki memiliki modal yang terbatas, bergantung pada alam, dan membutuhkan pengetahuan tentang peningkatan kemandirian ekonomi. Ada beberapa peluang yang dapat di manfaatkan dalam rangka meningkatkan kemandirian ekonomi masyarakat di Kampung Nelayan Belawan tersebut dilihat dari sudut pandang atau pendekatan politik lingkungan. Peluang-peluang tersebut ada empat. Peluang pertama, menjalankan usaha tambahan dengan melakukan wirausaha ramah lingkungan. Peluang kedua, memaksimalkan produksi dengan sistem pertanian terpadu. Peluang ketiga, menggagas dan mewujudkan kampung ekowisata. Peluang keempat, membangun unit usaha bersama seperti koperasi berbasis lingkungan.

Masyarakat pesisir khususnya di Kampung Nelayan perlu mendapat pelatihan-pelatihan dan penyuluhan. Misalnya saja membangun unit usaha bersama seperti koperasi berbasis lingkungan. Koperasi ini akan sangat bermanfaat dalam membantu masyarakat dalam mendapatkan modal, pembelian bibit, memasarkan hasil panen dan juga memasarkan hasil dari usaha mereka. Selain itu, membuat sebuah sentra kepiting bakau di Desa Nelayan. Langkah ini bisa menjadi langkah yang sangat baik bagi masyarakat, melihat potensi lingkungan dan sumber daya manusia yang sebagian besar memiliki usaha yang sama yaitu kepiting bakau.

\section{UCAPAN TERIMA KASIH}

Terima kasih kepada Lembaga Pengabdian Pada Masyarakat (LPPM) Universitas Sumatera Utara yang telah mendanai kegiatan pengabdian kepada masyarakat dengan judul: Pemberdayaan Masyarakat Pesisir dalam Upaya Meningkatkan Kewirausahaan dan Kemandirian di Desa Nelayan Belawan (Melalui Pendekatan Politik Lingkungan dan Sumber Daya Alam). Kegiatan Pengabdian Kepada Masyarakat ini dilaksanakan dengan Sumber Dana BPPTN Universitas Sumatera Utara, Pelaksanaan Pengabdian kepada Masyarakat Program Mono Tahun (Dosen Muda) Tahun Anggaran 2018, Nomor: 175/UN5.2.3.2.1/PPM/2018, Tanggal 16 April 2018.

\section{DAFTAR RUJUKAN}

Basyuni, M. (2016). Identifikasi Potensi dan Strategi Pengembangan Ekowisata Mangrove di Desa Lubuk Kertang, Kecamatan Brandan Barat, Kabupaten Langkat Sumatera Utara. Jurnal Abdimas Talenta, 1(1), 31-38.

Fatmasari, D. (2014). Analisis Sosial Ekonomi dan Budaya Masyarakat Pesisir Desa Waruduwur, Kecamatan Mundu, Kabupaten Cirebon. Jurnal Al-Mawal, 6(1), 144-166.

Haifaturrahmah. (2017). Pemanfataan Botol Plastik Bekas Sebagai Media Tanam Hidroponik dalam Meningkatkan Kesadaran Siswa Sekolah Dasar Terhadap 
Lingkungan Sekitar. Jurnal Masyarakat Mandiri (JMM), 1(1), 10-16.

Retrieved from https://doi.org/10.31764/jmm.v1i1.8

Rosmayati. (2018). Upaya Peningkatan Kemandirian dan Kewirausahaan Siswa

Melalui Program Sekolah Berkebun. Jurnal Abdimas Talenta, 3(1), 72-80.

Sugiarto, E. (2018). Pengantar Ekowisata. Yogyakarta: Khitah Publishing.

Syaharuddin. (2017). Aplikasi Sistem Informasi Desa Sebagai Teknologi Tepat

Guna Untuk Pendataan Penduduk Dan Potensi Desa. Jurnal Masyarakat Mandiri (JMM), 1(1), 60-67. Retrieved from https://doi.org/10.31764/jmm.v1i1.14

Zimmer, A. (2010). Urban Political Ecology: Theoretical Concept, Challenges, and Suggested Future Directions. Erkunde, 64(4), 343-354.

DOKUMENTASI KEGIATAN

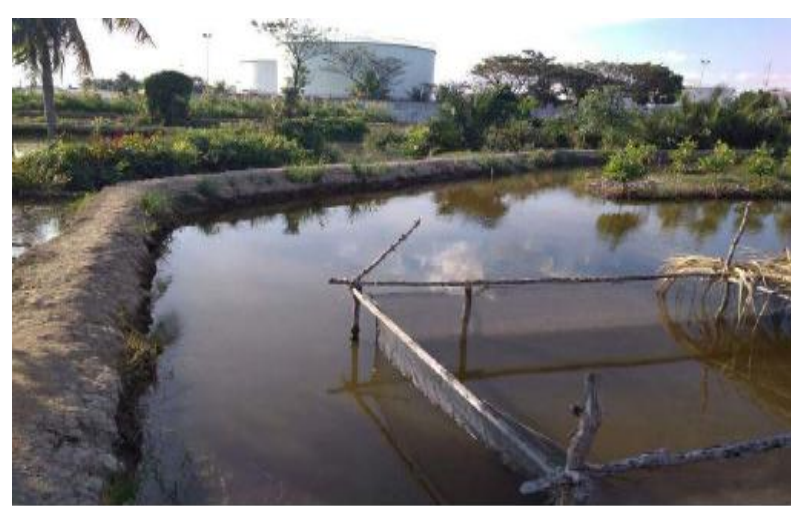

Gambar 1. Potensi Sistem Pertanian Terpadu di Kampung Nelayan

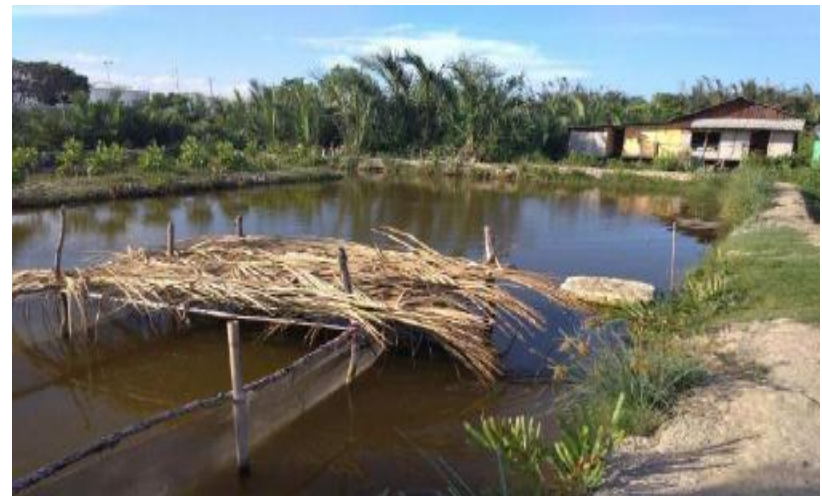

Gambar 2. Potensi Ekowisata di Kampung Nelayan 